\title{
Kejujuran dalam Praktik Pelaporan Manajerial: Tinjauan Literatur Sistematis
}

\author{
Dwi Rahma Fitriani \\ Universitas Airlangga \\ Jl. Airlangga No.4-6, Surabaya, Indonesia, 60115 \\ dwi.rahma.fitriani-2017@feb.unair.ac.id
}

\begin{abstract}
Agency theory is a widely adopted prominent management approach. The use of this theory has increased over time, but studies exploring managerial honesty in relation to reporting to shareholders are still limited. This study aims to identify the factors that influence honesty in managerial reporting using a systematic literature review method. Three databases were chosen to search for articles published from 2000 to 2018. The keywords used were honesty, managerial reporting, managerial behavior, and honesty determinant factors. From 1,720 articles identified using keywords search, 15 articles are the core articles which have been systematically reviewed. The results of the study find that the level of honesty in managerial reporting is driven by many factors such as the preference of individuals who have conducted trade-offs for honesty, the existence of profit-sharing plans, information and communication systems chosen by the company, individual morale and the role of peers. The most important efforts to improve honesty in the managerial sphere are starting from individual by committing to act honestly to improve integrity. By synthesizing findings from several articles studied, this study offers opportunities for various research and identify the steps for future research.
\end{abstract}

Keywords: Honesty, Managerial Behavior, Managerial Reporting, Individual Preferences, Systematic Literature Review

\begin{abstract}
Abstrak
Teori keagenan adalah pendekatan manajemen terkemuka yang telah banyak diadopsi. Penggunaan teori ini telah mengalami peningkatan dari waktu ke waktu, tetapi studi yang mengeksplorasi mengenai kejujuran manajerial dalam kaitannya dengan pelaporan kepada pemegang saham masih terbatas. Penelitian ini bertujuan untuk mengidentifikasi faktor-faktor yang mempengaruhi kejujuran dalam pelaporan manajerial dengan menggunakan metode tinjauan literatur sistematis. Tiga database dipilih untuk mencari artikel yang dipublikasikan dari tahun 2000 hingga 2018. Kata kunci yang digunakan adalah honesty, managerial reporting, managerial behavior, dan honesty determinant factor. Dari 1.720 artikel yang didapatkan dengan pencarian kata kunci, 15 artikel merupakan artikel inti yang secara sistematis telah ditinjau. Hasil penelitian menyoroti bahwa tingkat kejujuran dalam pelaporan manajerial didorong oleh banyak hal yaitu preferensi individu yang telah melakukan trade-off untuk kejujuran, adanya rencana pembagian keuntungan, sistem infomasi dan komunikasi yang dipilih perusahaan, moral individu serta peran rekan sejawat. Upaya untuk meningkatkan kejujuran di lingkup manajerial yang paling penting adalah dimulai dari dalam sendiri dengan berkomitmen untuk bertindak secara jujur demi meningkatkan integritas. Dengan mensintesis temuan dari beberapa artikel yang dikaji, maka akan membuka peluang pada berbagai aliran penelitian dan mengidentifikasi langkah-langkah untuk penelitian selanjutnya.
\end{abstract}

Kata Kunci: Kejujuran, Perilaku Manajerial, Pelaporan Manajerial, Preferensi Individu, Tinjauan Literatur Sistematis

\section{PENDAHULUAN}

Artikel ini berisi tinjauan literatur sistematis (systematic literature review) mengenai kejujuran dalam pelaporan manajerial dengan menggunakan teori keagenan sebagai dasar untuk meninjau motivasi manajemen untuk melakukan kejujuran maupun ketidakjujuran. Akuntansi manajemen melibatkan masalah pengukuran dan informasi dalam suatu perusahaan. Informasi dalam perusahaan digunakan untuk membantu mengevaluasi keputusan masa lalu hingga upaya untuk memperbaiki keputusan di masa mendatang. Keputusan-keputusan ini termasuk alokasi sumber 
daya dalam perusahaan, koordinasi lintas subunit, penetapan harga, penetapan biaya, dan kompensasi dan insentif. Teori keagenan adalah pendekatan manajemen terkemuka yang telah banyak diadopsi. Teori keagenan ini berakar pada literatur ekonomi informasi, dimana akuntansi dan informasi lainnya ditempatkan dalam pengaturan pengambilan keputusan yang eksplisit (Lambert, 2006). Nilai informasi berasal dari keputusan yang lebih baik (dan laba yang lebih tinggi) yang dihasilkan dari penggunaannya.

Dalam menjalankan perusahaan, adanya asimetri informasi antara pemilik (principal) dan manajemen sebagai agent tak dapat dihindari. Manajer sering memiliki informasi pribadi yang dapat bermanfaat bagi perusahaan. Sebagai contoh, manajer biasanya memiliki wawasan yang lebih luas ke dalam lingkungan bisnis lokal, termasuk biaya sumber daya, posisi pesaing, dan preferensi pelanggan. Jika tujuan tidak selaras, manajer mungkin menahan atau salah merepresentasikan informasi pribadi mereka untuk memaksimalkan kepentingan mereka sendiri. Karena asimetri informasi ini, perusahaan sering mengandalkan para manajer ini untuk berbagi informasi pribadi mereka selama proses penganggaran dan perencanaan. Manajer sering kali memiliki dorongan untuk salah melaporkan informasi pribadi mereka untuk keuntungan pribadi, yaitu terkait dengan slack. Dengan demikian, memotivasi manajer untuk mengkomunikasikan informasi pribadi mereka secara jujur selama proses penganggaran partisipatif adalah fungsi penting dari sistem pengendalian manajemen. Pelaporan yang jujur mengurangi sumber daya yang tidak perlu disediakan oleh perusahaan kepada manajer, yang dapat meningkatkan perencanaan dan keputusan koordinasi perusahaan serta meningkatkan keuntungannya (Indjejikian, 1999).

Menurut Murphy (1993) dalam Salterio dan Webb (2010), menggalakkan kejujuran dan menghalangi kebohongan adalah dua masalah manajerial berbeda yang tidak dapat ditangani dengan cara yang sama. Kebijakan untuk menggalakkan kejujuran dalam pengaturan organisasi melibatkan pemodelan perilaku jujur oleh semua pemimpin organisasi; memfasilitasi diskusi dan memberikan pelatihan tentang etika bisnis dalam konteks organisasi tertentu; serta menetapkan kebijakan, aturan, dan struktur (misalnya, kode perilaku, hotline untuk melaporkan perilaku buruk) yang diharapkan dapat mewujudkan perilaku jujur sebagai norma. Grover (2005) meneliti tentang penelitian organisasional dan sampai pada empat kesimpulan tentang kebohongan yaitu: (1) sulit untuk dideteksi; (2) sebagian disebabkan oleh kendala struktural (misalnya, sistem komputer yang memudahkan karyawan untuk berbohong daripada menemukan jawaban yang benar) dan konflik interpersonal (misalnya, kadang-kadang lebih mudah untuk berbohong daripada berurusan dengan konflik yang sebenarnya sedang terjadi); (3) ada perbedaan yang jelas pada individu ketika mereka berbohong; dan (4) struktur penghargaan (reward) yang dapat meningkatkan kemungkinan karyawan berbohong (misalnya, kuota penjualan yang tidak realistis, sistem evaluasi kinerja, dan lainnya). Pendekatan untuk mengurangi kebohongan dalam organisasi termasuk sistem pengawasan yang memperlakukan semua karyawan secara setara (misalnya, jika kamera berada di toilet staf, kamera tersebut juga harus ada di toilet eksekutif); nama karyawan yang telah tertangkap berbohong dilaporkan secara terbuka setidaknya di dalam organisasi; dan karyawan yang melaporkan perilaku tidak jujur dari orang lain secara terbuka akan dihargai (Salterio \& Webb, 2010).

Penelitian yang ada saat ini tidak hanya mempertimbangkan efek sosial, tetapi juga norma etis (Blay dkk., 2018). Pelaporan yang jujur (honest reporting)—kebalikan dari penciptaan slack yang disengaja dalam penganggaran-memungkinkan untuk memeriksa budgetary slack dari sudut pandang lain (Daumoser dkk., 2018). Abdel-Rahim dkk. (2018) menyatakan bahwa preferensi pribadi yang kuat atas kejujuran akan menghasilkan tiga penyelarasan terhadap suatu norma, bahkan ketika dihadapkan dengan tingginya asimetri informasi dan keuntungan secara finansial dari adanya pelaporan yang bias. Manajer yang menunjukkan preferensi kejujuran yang lebih lemah dapat dimotivasi oleh sanksi sosial untuk melaporkan dengan jujur.

Kejujuran sebagai sebuah konsep juga masuk dalam pembahasan psikologi positif, sama halnya dengan kajian lainnya seperti kebahagiaan (happiness), rasa syukur (gratitude), kemaafan (forgiveness) dan ketahanan (resilience). Konsep-konsep tersebut menjadi potensi bagi manusia (human strength), karena pengoptimalannya dapat membuat manusia menjadi lebih bahagia. Penerapan konsep kejujuran akan dapat membuat seseorang lebih tenang dan bahagia dalam hidupnya.

Beberapa penelitian tentang kejujuran dalam pelaporan manajerial telah tersebar dalam berbagai desain penelitian dan telah dipublikasikan dalam banyak jurnal ilmiah seperti Journal of Business Ethics, Journal of Management Accounting Research, The Accounting Review dan lain sebagainya. Sebagian besar penelitian tentang kejujuran dalam pelaporan manajerial yang ada 
menggunakan desain eksperimental. Oleh karena itu, penulis akan menyoroti kejujuran dalam pelaporan manajerial dengan menggunakan pendekatan analitis dan metodologis. Dengan demikian, tujuan utama dari penelitian adalah untuk mengidentifikasi faktor-faktor yang mempengaruhi kejujuran dalam pelaporan manajerial. Untuk mencapai tujuan tersebut, penulis menggunakan metode tinjauan literatur sistematis atas 15 jurnal utama yang dipublikasikan dalam jangka waktu antara tahun 2000-2018.

Artikel ini secara sistematis dibagi menjadi empat bagian. Bagian pertama membahas tentang gambaran umum perilaku kejujuran dalam lingkup manajerial dan teori yang relevan dengan kondisi ini, yaitu teori keagenan dan asimetri informasi. Bagian kedua menjelaskan metode yang dipilih yaitu metore tinjauan literatur sistematis. Metode ini dipilih dengan harapan agar tujuan penelitian dapat dicapai. Selanjutnya, bagian ketiga menyajikan hasil analisis deskriptif dan tematik serta diskusi atas beberapa hal perlu diperhatikan. Terakhir, bagian keempat berisi tentang kesimpulan yang dapat diambil dari beberapa pembahasan sebelumnya dan kontribusi penelitian ini serta saran untuk penelitian selanjutnya.

\section{METODE}

Penelitian ini didasarkan pada metodologi peninjauan sistematis (systematic review methodology) yang berbeda dari tinjauan konvensional karena transparan, dapat diakses dan memungkinkan untuk membentuk penyatuan antara masyarakat penelitian dan praktisi, yang mengarah ke sintesis keseluruhan (Thorpe dkk., 2005). Tinjauan literatur sistematis ini menggunakan proses yang digunakan oleh Klewitz dan Hansen (2014) yang terdiri dari enam langkah prosedural. Setiap langkah diilustrasikan pada Tabel 1 dan dijelaskan lebih lanjut sebagai berikut:

- Langkah 1. Mengidentifikasi kata kunci untuk pencarian yang diperoleh dari tinjauan teoritis.

- Langkah 2. Tinjauan sistematis dapat mencakup berbagai jenis publikasi. Analisis dalam penelitian ini terkonsentrasi pada makalah jurnal akademik yang telah direviu dan ditulis dalam Bahasa Inggris untuk menjamin kualitas dan mengurangi sampel ke jumlah yang dapat dikelola seperti dalam literatur lain. Oleh karena itu, ulasan ini mencakup makalah akademik yang diterbitkan dari 2000 hingga 2018.

- Langkah 3 dan 4. Tinjauan ini mencakup beberapa database penelitian utama berikut: Scopus, Emerald Insight dan Science Direct. Setiap database dan mesin pencari tersebut bekerja secara berbeda, dengan demikian, pencarian disesuaikan dengan yang diperlukan. Dalam makalah ini, semua pencarian artikel berada dalam kisaran istilahistilah kunci. Awalnya, penulis memulai dengan database dari artikel dikategorikan menjadi A (paling relevan), B (kurang relevan), dan C (tidak relevan). Daftar awal dari 1.720 (daftar C) dikurangi menjadi 47 artikel yang relevan (daftar B) berdasarkan judul dan analisis abstrak. Selanjutnya, dari 47 artikel tersebut, 29 diantaranya diunduh dalam format PDF sedangkan 18 artikel lainnya tidak dapat diunduh dikarenakan keterbatasan akses. Makalah ini dianalisis dengan berkonsentrasi pada judul, bagian abstrak dan relevansi dari teks lengkap. Alasan paling umum untuk memilih artikel untuk Daftar A adalah fokus yang kuat pada honesty in managerial reporting. Daftar A, dengan 15 artikel, kemudian diteliti lebih lanjut dengan menggunakan analisis deskriptif dan tematik.

- Langkah 5. Untuk analisis deskriptif, artikel dikelompokkan berdasar kategori seperti tahun publikasi, jurnal, negara yang difokuskan dalam studi, klasifikasi makalah, metodologi, temuan, dan teori.

- Langkah 6. Tujuan analisis tematik adalah untuk secara sistematis mengkategorikan isi makalah dan mengidentifikasi hubungan (Lane dkk., 2006). Proses sintesis ini bersifat induktif dan interpretatif. Hasilnya disusun menjadi dua bagian. Pertama analisis deskriptif kuantitatif (bibliografi) untuk mendapatkan gambaran umum agenda penelitian terkait kejujuran dalam pelaporan manajerial. Kedua, analisis tematik kualitatif untuk memberikan analisis mendalam tentang kejujuran dalam pelaporan manajerial. 
Tabel 1. Langkah-Langkah Tinjauan Literatur Sistematis

\begin{tabular}{|c|c|c|c|c|}
\hline Overall Process & Langkah & Uraian & $\begin{array}{l}\text { Analisis yang } \\
\text { dihasilkan }\end{array}$ & $\begin{array}{l}\text { Jumlah } \\
\text { Artikel }\end{array}$ \\
\hline \multirow[t]{7}{*}{ Proses pencarian } & 1 & $\begin{array}{l}\text { Identifikasi kata kunci (honesty, } \\
\text { managerial reporting, } \\
\text { behavior,determinant factor) }\end{array}$ & $\begin{array}{l}\text { Penelitian dan tinjauan } \\
\text { sebelumnya }\end{array}$ &.$\%$ \\
\hline & 2 & $\begin{array}{l}\text { Pengembangan kriteria eksklusi } \\
\text { dan inklusi }\end{array}$ & .1. &.$\%$ \\
\hline & 3 & $\begin{array}{l}\text { Spesifikasi mesin pencari yang } \\
\text { relevan dan pelaksanaan pencarian } \\
\text { ( } 3 \text { databese: Scopus, Emerald } \\
\text { Insight dan Science Direct) }\end{array}$ & $\begin{array}{l}\text { Judul dan abstrak } \\
\text { (berbasis otomatis } \\
\text { pada kata kunci) }\end{array}$ & 12.284 \\
\hline & 4 & Mengembangkan daftar A, B, C & .1 & \\
\hline & & Daftar C & Judul dan abstrak & 1720 \\
\hline & & Daftar B & (manual) & 47 \\
\hline & & Daftar A & Fulltext & 29 \\
\hline \multirow[t]{2}{*}{$\begin{array}{l}\text { Analisis } \\
\text { deskriptif dan } \\
\text { tematik }\end{array}$} & 5 & $\begin{array}{l}\text { Kategori deskriptif (misalnya, } \\
\text { jurnal yang dicakup, metodologi } \\
\text { yang diterapkan) }\end{array}$ & & 15 \\
\hline & 6 & $\begin{array}{l}\text { Kategori deduktif dan induktif } \\
\text { untuk mengidentifikasi tema } \\
\text { sentral dan menafsirkan hasil }\end{array}$ & & 15 \\
\hline
\end{tabular}

\section{HASIL DAN PEMBAHASAN}

Hasil analisis tinjauan literatur sistematis dalam artikel ini terbagi menjadi 2 bagian, yaitu hasil analisis deskriptif dan hasil analisis tematik.

\section{Hasil Analisis Deskriptif}

Analisis deskriptif dalam penelitian ini meliputi distribusi artikel berdasarkan tahun publikasi dan metode yang digunakan oleh masing-masing artikel. Dari lima belas (15) artikel yang telah dikumpulkan sebelumnya (dengan mempertimbangkan kesesuaiannya dengan topik yang dibahas dalam penelitian ini), empat artikel diantaranya berasal dari publikasi tahun 2015. Jumlah ini merupakan jumlah terbesar jika dibandingkan dengan tahun lainnya. Jumlah terbesar kedua adalah tahun 2014 dan 2018 yang masing-masing memberikan 3 artikel, 2 artikel dari tahun 2010, sedangkan 3 artikel sisanya berasal dari tahun 2001, 2006 dan 2016. Distribusi artikel ini secara lebih rinci ditunjukkan di Gambar 1.

Di antara berbagai metode yang diadopsi, 13 artikel adalah penelitian tindakan, diikuti dengan dua yang merupakan makalah konseptual. Metode penelitian yang paling banyak dipakai dalam artikel yang telah dikumpulkan adalah penelitian eksperimental yaitu 13 dari 15 artikel. Metode tinjauan pustaka (literature review) digunakan di dua artikel lainnya. Studi kualitatif masih sangat terbatas, mungkin karena kesulitan yang terkait dengan pengumpulan data.

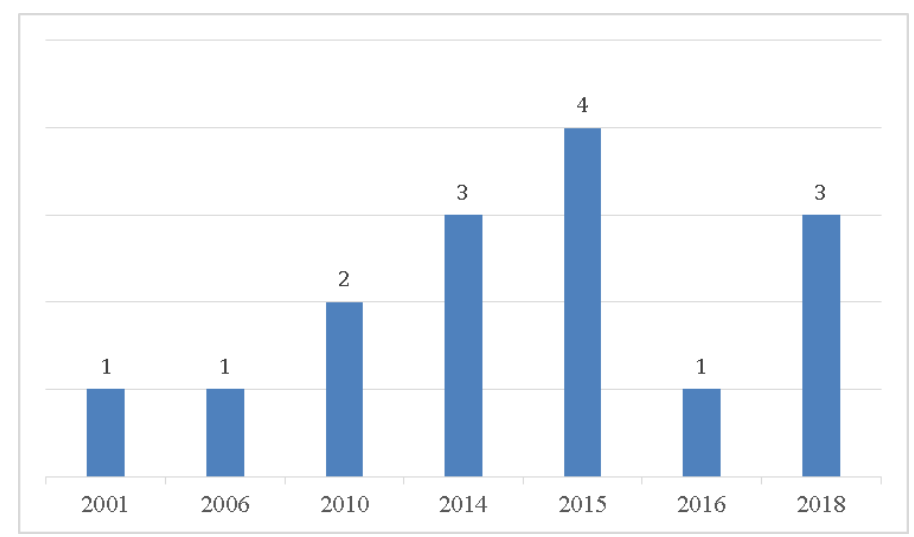

Gambar 1. Distribusi Artikel berdasarkan Tahun Publikasi (Sumber: Data Diolah) 
Beberapa latar belakang teoritis dikutip dalam semua artikel yang dianalisis dalam penelitian ini. Namun, sebagian besar makalah juga mengacu pada teori tambahan, terutama teori etika dan teori agensi, diikuti dengan teori institusional. Hasil ini menggarisbawahi kebutuhan untuk menghubungkan kejujuran manajer dengan teori keagenan untuk memperkuat pemahaman tentang kontribusinya terhadap praktik perusahaan terutama dalam pembuatan pelaporan.

\section{Hasil Analisis Tematik}

Tujuan penggunaan analisis tematik adalah untuk mengorganisasikan pandangan komprehensif dari artikel yang diterbitkan terkait dengan kejujuran (honesty) dalam praktek pelaporan manajerial. Dengan menggunakan metode induktif, artikel yang dipilih telah diklasifikasikan berdasarkan dua kriteria. Klasifikasi pertama difokuskan pada faktor yang tidak berhubungan dengan finansial yang pendorong kejujuran atau ketidakjujuran (honesty/ dishonesty) pada praktek pelaporan manajerial yaitu sistem informasi dan komunikasi perusahaan, aspek moral dan peran rekan sejawat. Taksonomi kedua mempertimbangkan faktor pendorong yang faktor yang berhubungan dengan finansial yaitu preferensi individu atas kekayaan (wealth) dan adanya rencana pembagian keuntungan (profit-sharing plan). Pembagian kedua taksonomi ini secara sistematis ditunjukkan dalam Tabel 2.

Tabel 2. Taksonomi Fokus Penelitian

\begin{tabular}{|c|c|c|c|}
\hline No. & Peneliti & Fokus & Temuan \\
\hline \multicolumn{4}{|c|}{ Faktor - Faktor yang Tidak Berhubungan dengan Finansial } \\
\hline 1 & $\begin{array}{l}\text { Hannan dkk. } \\
\qquad(2006)\end{array}$ & Sistem informasi & $\begin{array}{l}\text { Keberadaan sistem informasi meningkatkan kejujuran } \\
\text { manajerial, namun tingkat kejujuran akan lebih rendah ketika } \\
\text { sistem informasi bersifat lebih tepat (precise) daripada ketika } \\
\text { sistem informasi bersifat kasar (coarse). }\end{array}$ \\
\hline 2 & $\begin{array}{l}\text { Salterio dan } \\
\text { Webb } \\
(2010)\end{array}$ & Sistem informasi & $\begin{array}{l}\text { Sistem pengendalian manajemen dapat digunakan untuk } \\
\text { membatasi perilaku tidak jujur (dishonesty), yang sebelumnya } \\
\text { telah diteliti oleh Hannan dkk (2006). }\end{array}$ \\
\hline 3 & $\begin{array}{l}\text { Abdel- } \\
\text { Rahim dkk. } \\
\text { (2018) }\end{array}$ & Sistem informasi & $\begin{array}{l}\text { Tingkat kejujuran tertinggi terjadi ketika sistem informasi } \\
\text { yang tepat (precise) diterapkan dengan akurasi tinggi. Sistem } \\
\text { informasi yang tepat meningkatkan kejujuran manajerial. } \\
\text { Temuan ini kontras dengan temuan Hannan dkk (2006). }\end{array}$ \\
\hline 4 & $\begin{array}{l}\text { Cardinaels } \\
\quad(2016)\end{array}$ & Sistem informasi & $\begin{array}{l}\text { Dampak dari situasi laba pada tingkat kejujuran tergantung } \\
\text { pada apakah perusahaan menggunakan sistem informasi yang } \\
\text { meningkatkan kemampuannya untuk mendeteksi kesalahan } \\
\text { pelaporan. Secara khusus, situasi pendapatan kurang } \\
\text { berpengaruh pada tingkat kejujuran ketika perusahaan } \\
\text { menggunakan sistem informasi. }\end{array}$ \\
\hline 5 & $\begin{array}{l}\text { Newman } \\
(2014)\end{array}$ & $\begin{array}{l}\text { Komunikasi } \\
\text { informal atas } \\
\text { penetapan target }\end{array}$ & $\begin{array}{l}\text { Komunikasi informal perusahaan terkait target dapat } \\
\text { memotivasi kejujuran manajerial. }\end{array}$ \\
\hline 6 & $\begin{array}{l}\text { Altenburger } \\
\quad(2017)\end{array}$ & $\begin{array}{l}\text { Norma injunctive } \\
\text { di lingkup rekan } \\
\text { sejawat }\end{array}$ & $\begin{array}{l}\text { Norma-norma injunctive dapat memiliki pengaruh yang besar } \\
\text { pada perilaku pelaporan anggaran manajer karena banyak } \\
\text { orang sesuai dengan preferensi kelompok rekan sejawat } \\
\text { mereka. }\end{array}$ \\
\hline 7 & $\begin{array}{l}\text { Brunner dan } \\
\text { Ostermaier } \\
\quad(2017)\end{array}$ & $\begin{array}{l}\text { Peran rekan } \\
\text { sejawat }\end{array}$ & $\begin{array}{l}\text { Terdapat interaksi antara transparansi (penuh \& parsial) dan } \\
\text { pengaruh teman sebaya dalam memicu ketidakjujuran. } \\
\text { Transparansi juga dapat merugikan perusahaan yang } \\
\text { mendorong norma-norma kejujuran (seperti dalam kode etik) } \\
\text { tetapi gagal menegakkan kepatuhan. }\end{array}$ \\
\hline
\end{tabular}




\begin{tabular}{ccccc}
\hline No. & Peneliti & Fokus & \multicolumn{3}{c}{ Temuan } \\
\hline \multicolumn{1}{c}{ Faktor - Faktor yang Tidak Berhubungan dengan Finansial } \\
\hline 8 & $\begin{array}{c}\text { Schwering } \\
(2017)\end{array}$ & Peran rekan sejawat & $\begin{array}{l}\text { Adanya pengungkapan kejujuran oleh rekan sejawat, } \\
\text { mengurangi kejujuran dari waktu ke waktu untuk } \\
\text { pengungkapan anonim dan non-anonim. }\end{array}$ \\
\hline 9 & Schreck (2015) & Persaingan & $\begin{array}{l}\text { Kesediaan individu untuk melaporkan secara jujur } \\
\text { menurun secara signifikan ketika dihadapkan dengan } \\
\text { persaingan. }\end{array}$ \\
\hline 10 & $\begin{array}{c}\text { Daumoser dkk. } \\
(2018)\end{array}$ & $\begin{array}{c}\text { Norma sosial \& } \\
\text { rekan sejawat }\end{array}$ & $\begin{array}{l}\text { Analisis mengungkapkan bahwa norma-norma sosial } \\
\text { mengurangi slack dan pengaruh rekan sejawat memoderasi } \\
\text { efek tersebut. }\end{array}$ \\
\hline 11 & $\begin{array}{c}\text { Chung dan Hsu } \\
(2017)\end{array}$ & $\begin{array}{c}\text { Perkembangan } \\
\text { moral kognitif }\end{array}$ & $\begin{array}{l}\text { Terdapat hubungan positif dan linier antara honest } \\
\text { reporting dengan perkembangan moral kognitif. }\end{array}$ \\
\hline
\end{tabular}

Faktor - Faktor yang Berhubungan dengan Finansial

\begin{tabular}{|c|c|c|c|}
\hline 12 & $\begin{array}{l}\text { Evans dkk. } \\
\qquad(2001)\end{array}$ & $\begin{array}{c}\text { Preferensi atas } \\
\text { kekayaan (wealth) }\end{array}$ & $\begin{array}{l}\text { Tingkat kejujuran dapat bergantung pada bagaimana } \\
\text { surplus dibagi antara manajer dan perusahaan. Preferensi } \\
\text { atas kekayaan (wealth) dan kejujuran mempengaruhi } \\
\text { pelaporan manajerial. }\end{array}$ \\
\hline 13 & $\begin{array}{l}\text { Matuszewski } \\
\quad(2010)\end{array}$ & $\begin{array}{l}\text { Preferensi atas } \\
\text { kekayaan (wealth) } \\
\text { dan kesetaraan } \\
\text { horizontal }\end{array}$ & $\begin{array}{l}\text { Individu melakukan trade-off antara preferensi kekayaan, } \\
\text { kejujuran, dan kesetaraan horizontal, dan bahwa } \\
\text { perusahaan yang berusaha mengeksploitasi preferensi } \\
\text { kejujuran harus berusaha untuk menghindari } \\
\text { ketidakadilan. }\end{array}$ \\
\hline 14 & $\begin{array}{l}\text { Drake dkk. } \\
\quad(2014)\end{array}$ & $\begin{array}{l}\text { Preferensi atas } \\
\text { kekayaan (wealth) }\end{array}$ & $\begin{array}{l}\text { Preferensi yang lebih tinggi atas kejujuran yang secara } \\
\text { signifikan terkait dengan kejujuran dalam pelaporan, } \\
\text { menunjukkan bahwa peserta membuat trade-off antara } \\
\text { meningkatkan kekayaan mereka sendiri atau bertindak } \\
\text { jujur. }\end{array}$ \\
\hline 15 & $\begin{array}{l}\text { Boster dkk. } \\
\quad(2018)\end{array}$ & Profit-sharing plan & $\begin{array}{l}\text { Kejujuran berkurang dengan adanya rencana pembagian } \\
\text { keuntungan individual. }\end{array}$ \\
\hline
\end{tabular}

\section{Faktor yang Tidak Berhubungan dengan Finansial}

Pendekatan induktif yang diterapkan pada analisis artikel atas faktor yang tidak berhubungan dengan finansial terbagi menjadi tiga bahasan. Pertama adalah sistem informasi dan komunikasi yang mencakup tentang kualitas sistem informasi yang dimiliki perusahaan dan cara yang dipilih manajemen untuk saling berkomunikasi antar sesama. Kedua adalah aspek moral, yang mengacu pada perkembangan moral kognitif individu yang memungkinkan mempengaruhi tindakan yang nantinya akan diambil oleh individu itu sendiri. Ketiga, meninjau peran rekan sejawat yang mungkin selaras dengan norma yang berlaku atau bahkan bertentangan dengan norma serta persaingan yang timbul di antara mereka.

Cardinaels (2016) memaparkan dalam studinya bahwa adanya sistem informasi akan meningkatkan kejujuran manajemen dalam membuat pelaporan manajerial. Senada dengan hal tersebut, Hannan dkk. (2006) juga menemukan bahwa kejujuran dalam laporan anggaran manajer dipengaruhi oleh sistem informasi. Di samping itu, disebutkan pula bahwa kejujuran terkait permasalahan anggaran dapat ditingkatkan dengan mengurangi asimetri informasi antara manajer dan pemilik. Kedua peneliti tersebut menemukan bahwa efek peralihan dari tidak adanya sistem informasi ke sistem informasi bermutu rendah akan meningkatkan kejujuran dalam pelaporan manajerial. Namun, mereka juga melaporkan bahwa efek peralihan dari sistem informasi bermutu rendah ke sistem informasi yang tepat (precise) akan mengurangi kejujuran dalam pelaporan manajerial. Salterio dan Webb (2010) melakukan studi lanjutan mengenai cara untuk membatasi perilaku tidak jujur (dishonesty), yang sebelumnya telah diteliti oleh Hannan dkk. (2006), dengan menggunakan sistem pengendalian manajemen. Terjadinya kebohongan atau ketidakjujuran yang 
dibahas dalam beberapa literatur sistem pengendalian manajemen dapat dikurangi dengan penggunaan sistem informasi yang lebih baik karena pengurangan lebih lanjut dalam asimetri informasi yang diberikan. Sementara itu, Abdel-Rahim dkk. (2018) menunjukkan temuan yang kontras dengan temuan Hannan dkk. (2006). Tingkat kejujuran tertinggi terjadi ketika sistem informasi yang tepat (precise) diterapkan dengan akurasi tinggi. Sistem informasi yang tepat meningkatkan kejujuran manajerial. Selain sistem informasi, komunikasi informal yang dipilih perusahaan terkait penetapan target dapat memotivasi kejujuran manajerial

Altenburger (2017) melakukan studi yang berfokus pada efek norma-norma injungtif atas kejujuran/oportunisme pada pelaporan anggaran kejujuran. Perilaku pelaporan anggaran manajer sebagian besar dipengaruhi oleh norma-norma injungtif. Hal ini dikarenakan banyak orang cenderung lebih memilih untuk menyesuaikan diri dengan preferensi kelompok rekan sejawat mereka. Dari segi moral, Chung dan Hsu (2017) menemukan bahwa terdapat hubungan positif dan linier antara honest reporting dengan perkembangan moral kognitif. Para partisipan yang berada pada tahapan per-kembangan moral kognitif yang lebih tinggi, dimana mereka bertindak karena suatu hal itu "benar", lebih mungkin untuk menyerahkan laporan yang jujur dengan melepaskan potensi keuntungan moneter yang akan diperoleh dari kebohongan dibandingkan dengan partisipan lain yang berada pada tahapan perkembangan moral kognitif yang lebih rendah.

Kemungkinan seseorang melakukan kejujuran (ketidakjujuran) dalam pelaporan manajerial juga tidak terlepas dari peran rekan sejawat (Brunner \& Ostermaier, 2017; Daumoser dkk., 2018; Schwering, 2017). Adanya pengungkapan kejujuran oleh rekan sejawat akan mengurangi kejujuran dari waktu ke waktu, baik untuk pengungkapan yang dilakukan secara anonim maupun non-anonim (Schwering, 2017). Sementara itu, ketika dihadapkan dengan persaingan, kesediaan individu untuk melaporkan secara jujur menurun secara signifikan. Untuk mengurangi pengaruh teman sejawat yang berakibat pada ketidakjujuran, maka perusahaan perlu menegakkan peraturan yang selaras dengan norma-norma sosial (Daumoser dkk., 2018).

\section{Faktor yang Berhubungan dengan Finansial}

Hasil analisis kedua dari tinjauan literatur sistematis ini mempertimbangkan tentang faktor pendorong yang berhubungan dengan finansial, yaitu preferensi individu atas kekayaan (wealth) dan adanya rencana pembagian keuntungan (profit-sharing plan). Tingkat kejujuran dapat bergantung pada bagaimana surplus dibagi antara manajer dan perusahaan. Preferensi individu atas kekayaan (wealth) dan kejujuran mempengaruhi pelaporan manajerial (Evans dkk., 2001). Menurut Matuszewski (2010), individu melakukan trade-off antara preferensi kekayaan, kejujuran, dan ke-setaraan horizontal, dan bahwa perusahaan yang berusaha mengeksploitasi preferensi kejujuran harus berusaha untuk menghindari ketidakadilan. Ketika ekuitas horizontal meningkat karena meningkatnya gaji seseorang (sementara gaji rekan sejawat lainnya tetap konstan), maka perubahan kejujuran secara signifikan akan berbeda dibandingkan ketika ekuitas horisontal meningkat karena adanya pengurangan gaji rekan sejawat yang lain, sedangkan gaji seseorang tersebut tetap konstan. Preferensi individu atas kejujuran dalam pelaporan, menunjukkan bahwa individu tersebut membuat trade-off antara pilihan meningkatkan kekayaan mereka sendiri atau memilih bertindak jujur (Drake dkk., 2014).

Boster dkk. (2018) menyebutkan bahwa kejujuran akan berkurang karena adanya rencana pembagian keuntungan individual (individual profit-sharing plan). Namun, ketika rencana pembagian laba gabungan (pooled profit-sharing plan) diterapkan, efek buruk pada kejujuran akan dapat dikurangi secara parsial. Hasil ini menunjukkan bahwa interdependensi dari rencana gabungan dapat mengurangi konsekuensi yang tidak diinginkan dari pembagian keuntungan.

\section{Pembahasan}

Berdasarkan analisis sistematis yang telah dilakukan, faktor-faktor yang mempengaruhi kejujuran dalam pelaporan manajerial terbagi menjadi dua kategori yaitu faktor yang berkaitan dengan finansial dan yang tidak berkaitan dengan finansial. Faktor yang berkaitan dengan finansial terdiri dari preferensi individu atas kekayaan (wealth) dan adanya rencana pembagian keuntungan (profit-sharing plan). Sementara itu, faktor yang tidak berkaitan dengan finansial terdiri dari sistem informasi dan komunikasi perusahaan, aspek moral dan peran rekan sejawat.

Tiap-tiap individu memiliki alasan untuk bertindak jujur maupun sebaliknya. Sebagian individu memilih untuk berbohong karena semakin banyak mereka berbohong akan semakin besar pula keuntungan yang mereka peroleh, dan karena tidak adanya pemantauan, tindakan audit serta 
dampak yang nyata pada reputasi maka hal ini berarti mereka tidak akan mendapatkan konsekeunsi negatif apapun sebagai akibat dari kebohongan yang dibuatnya (Evans dkk., 2001). Namun, di sisi lain, beberapa individu memilih mengorbankan kekayaan (wealth) mereka untuk membuat laporan yang jujur. Dalam hal ini akan nampak adanya trade-off, yaitu ketika seseorang lebih memilih untuk jujur maka kekayaan akan dikorbankan. Demikian sebaliknya, ketika kekayaan lebih diprioritaskan maka kejujuran mereka yang akan dikorbankan. Salah satu upaya yang dapat dilakukan perusahaan untuk memotivasi karyawan agak berperilaku jujur adalah dengan memberikan pembagian keuntungan antara manajer dan perusahaan. Rencana pembagian keuntungan (profit-sharing plan) yang jelas dan bersifat gabungan (pooled profit-sharing plan) akan meningkatkan kejujuran karyawan (Boster dkk., 2018). Dalam suatu rencana pembagian keuntungan gabungan (pooled profit-sharing plan), semua karyawan dari gabungan beberapa divisi saling berbagi dalam kelompok besar tersebut. Setiap keputusan manajerial yang mempengaruhi profitabilitas, secara langsung akan berdampak pada kesejahteraan semua karyawan yang ada di dalamnya. Saling ketergantungan antar karyawan ini dapat meningkatkan tekanan yang dirasakan seorang karyawan untuk melaporkan secara jujur dan menghindari kesalahan pelaporan.

Faktor-faktor yang tidak berkaitan dengan finansial juga mendorong perilaku seseorang untuk bertindak jujur maupun tidak jujur, seperti sistem informasi, moral serta peran rekan sejawat di lingkup perusahaan. Sistem informasi yang dipilih perusahaan dapat memberikan pengaruh yang cukup besar. Sistem informasi yang tepat akan memotivasi karyawan untuk menjadi jujur, bahkan Salterio dan Webb (2010) menyebutkan bahwa sistem pengendalian manajemen dapat digunakan untuk membatasi perilaku karyawan yang tidak jujur. Kejujuran maupun ketidakjujuran manajer seringkali muncul akibat adaya asimetri informasi yang tinggi. Namun, dengan adanya sistem informasi yang tepat, maka asimetri informasi ini dapat dikurangi, sehingga kejujuran dapat ditingkatkan. Peran rekan sejawat juga dapat mempengaruhi seseorang untuk bertindak jujur atau tidak. Persaingan yang tinggi bisa mendorong pihak manajemen untuk melakukan segala upaya yang nantinya diharapkan dapat membuatnya memenangkan persaingan. Sementara itu, rekan sejawat juga dapat memberikan peran kontrol atau pengawasan, dimana sesama karyawan dapat saling menegur dan mengingatkan karyawan lain yang tidak jujur. Namun, preferensi sebagian besar rekan sejawat juga dapat membuat seseorang untuk menyesuaikan diri dengan preferensi mereka. Hal ini sejalan dengan penelitian Altenburger (2017) yang menyebutkan bahwa pelaporan manajerial sebagian besar dipengaruhi oleh norma injungtif, yaitu pilihan seseorang untuk menyesuaikan diri dengan kelompok dimana dia berada. Ketika rekan sejawat mampu menjaga kejujuran dalam membuat pelaporan manajerial, maka peluang karyawan lain untuk melakukan ketidakjujuran akan semakin kecil. Selain berkaitan dengan norma injungtif, pelaporan yang jujur juga memiliki hubungan linier yang positif dengan perkembangan moral kognitif (Chung \& Hsu, 2017). Seseorang yang memiliki perkembangan kognitif yang tinggi cenderung membuat pelaporan yang jujur karena mereka merasa telah melakukan apa yang telah dianggap "benar".

Hasil analisis telah menunjukkan banyak hal yang mendorong seseorang, terutama manajer untuk bertindak tidak jujur. Manajemen yang jujur sudah selayaknya harus mengedepankan penyajian fakta yang sesungguhnya terjadi di dalam perusahaan. Kejujuran dalam hal ini dapat diartikan sebagai satunya kata dengan perbuatan serta upaya menghindarkan diri dari konflik kepentingan. Kejujuran yang dihubungkan dengan pelaksanaan suatu amanah akan dapat mengarah menjadi integritas dan berorientasi pada pelaksanaan tugas. Kejujuran dalam lingkup manajerial bisa terpengaruh oleh banyak hal. Namun, semua itu akan kembali ke dalam diri masing-masing individu itu sendiri. Sebaik apapun sistem yang dirancang perusahaan untuk menghapus ketidakjujuran, masih ada kemungkinan ada celah yang memungkinkan seseorang untuk bertindak tidak jujur jika dalam diri orang tersebut tidak ada komitmen untuk bersikap jujur. Jadi, semuanya kembali kepada diri sendiri.

Kebijakan untuk menggalakkan kejujuran dalam pengaturan organisasi melibatkan pemodelan perilaku jujur oleh semua pemimpin organisasi, memfasilitasi diskusi dan memberikan pelatihan tentang etika bisnis dalam konteks organisasi tertentu, dan menetapkan kebijakan, aturan, dan struktur (misalnya, kode perilaku, hotline untuk melaporkan perilaku yang menyimpang) yang menetapkan harapan untuk perilaku jujur sebagai norma.

\section{SIMPULAN DAN SARAN}

Adanya asimetri informasi telah membuka peluang bagi manajemen untuk berperilaku jujur maupun tidak jujur. Manajemen mempunyai informasi yang lebih banyak dibandingkan dengan 
pemilik perusahaan. Kondisi ini dapat menjadi salah satu sumber potensial yang nantinya akan dimanfaatkan oleh manajemen untuk membuat pelaporan yang cenderung lebih menguntungkan mereka hingga menyajikan informasi yang tidak sebenarnya atau tidak jujur. Secara keseluruhan, hasil penelitian menyoroti bahwa tingkat kejujuran dalam pelaporan manajerial didorong oleh banyak hal yaitu preferensi individu yang telah melakukan trade-off untuk kejujuran, adanya rencana pembagian keuntungan, sistem infomasi dan komunikasi yang dipilih perusahaan, moral individu serta peran rekan sejawat. Upaya untuk meningkatkan kejujuran di lingkup manajerial yang paling penting adalah dimulai dari dalam sendiri dengan berkomitmen untuk bertindak secara jujur untuk meningkatkan integritas.

Kesimpulan dalam studi ini memiliki implikasi akademik dan manajerial. Implikasi bagi akademisi, peneliti menyarankan agar asosiasi dan jurnal harus mendukung realisasi proyek dan publikasi tentang topik yang dibahas. Dalam pengertian ini, lebih banyak membuka peluang untuk proposal dan makalah yang akan memfasilitasi pengembangan di masa depan. Di sisi lain, jurnal dapat mempromosikan publikasi lebih banyak untuk studi kualitatif dengan menggunakan set data yang luas untuk memfasilitasi pemahaman yang luas tentang pelaporan manajerial. Bagi manajerial, penelitian ini menunjukkan faktor-faktor yang mempengaruhi kejujuran dalam laporan manajerial, sehingga, beberapa faktor tersebut dapat dijadikan sebagai salah satu bahan pertimbangan untuk menggalakkan kejujuran dalam pelaporan manajerial di lingkup kerja masing -masing.

Penelitian ini telah memberikan sebuah gagasan kecil tentang faktor yang mempengaruhi kejujuran seseorang dalam konteks pelaporan manajerial. Oleh karena itu, akan bermanfaat bagi penelitian masa depan untuk mempertimbangkan saran-saran berikut: (1) Penelitian selanjutnya dapat memperbesar studi dengan ukuran sampel yang besar, serta mempertimbangkan ke industri lain dengan memeriksa hubungan kejujuran dalam pelaporan manajerial. Eksplorasi semacam ini akan membantu memberikan rincian perbandingan antara aspek komitmen organisasi dalam meningkatkan kejujuran. (2) Penelitian selanjutnya juga disarankan untuk mengeksplorasi sebab dan akibat dari kejujuran dalam pelaporan manajerial sehingga dapat diperoleh pemahaman yang utuh agar dapat meningkatkan kejujuran manajerial yang tidak merugikan pihak manajemen (agent) maupun para pemegang saham (principal).

\section{DAFTAR RUJUKAN}

Abdel-Rahim, Y, H., \& Stevens, D. E. (2018). Information system precision and honesty in managerial reporting: A re-examination of information asymmetry effects. Accounting, Organizations and Society, 64, 31-43.

Altenburger, M. (2017). The effect of injunctive social norms and dissent on budget reporting honesty. Journal of International Accounting Research, 16(2), 9-31.

Blay, A. D., Gooden, E. S., Mellon, M. J., \& Stevens, D. E. (2018). The usefulness of social norm theory in empirical business ethics research: A review and suggestions for future research. Journal of Business Ethics, 152(1), 191-206.

Boster, C., Majerczyk, M., \& Tian, Y. (2018). The Effect of Individual and Pooled Profit Sharing Plans on Honesty in Managerial Reporting. Contemporary Accounting Research, 35(2), 696-715.

Brunner, M., \& Ostermaier, A. (2017). Peer influence on managerial honesty: The role of transparency and expectation. The Journal of Business Ethics.

Cardinaels, E. (2016). Earnings benchmarks, information systems, and their impact on the degree of honesty in managerial reporting. A ccounting, Organizations and Society, 52, 50-62.

Chung, J. O., \& Hsu, S. H. (2017). The effect of cognitive moral development on honesty in managerial reporting. Journal of Business Ethics, 145(3), 563-575.

Daumoser, C., Hirsch, B., \& Sohn, M. (2018). Honesty in budgeting: a review of morality and control aspects in the budgetary slack literature. Journal of Management Control, 29(2), 115-159.

Drake, A. R., Matuszewski, L. J., \& Miller, F. (2014). The effect of personality traits and fairness on honesty in managerial reporting. Advances in management accounting, 43-69.

Evans, J. H., Hannan, R. L., Krishnan, R., \& Moser, D. V. (2001). Honesty in managerial reporting. The Accounting Review, 76(4), 537-559.

Grover, S. L. (2005). The truth, the whole truth, and nothing but the truth: The causes and management of workplace lying. Academy of Management Perspectives, 19(2), 148-157. 
Hannan, R. L., Rankin, F. W., \& Towry, K. L. (2006). The effect of information systems on honesty in managerial reporting: A behavioral perspective. Contemporary Accounting Research, 23(4), 885-918.

Indjejikian, R. J. (1999). Performance evaluation and compensation research: An agency perspective. Accounting Horizons, 13(2), 147-157.

Klewitz, J., \& Hansen, E. G. (2014). Sustainability-oriented innovation of SMEs: a systematic review. Journal of cleaner production, 65, 57-75.

Lambert, R. A. (2006). Agency Theory and Management Accounting. Handbooks of management accounting research, 1, 247-268.

Lane, P. J., Koka, B. R., \& Pathak, S. (2006). The reification of absorptive capacity: A critical review and rejuvenation of the construct. Academy of management review, 31(4), 833863.

Matuszewski, L. J. (2010). Honesty in managerial reporting: Is it affected by perceptions of horizontal equity? Journal of Management Accounting Research, 22(1), 233-250.

Murphy, K. (1993). Honesty in the workplace. Pasific Groves: Brooks.

Newman, A. H. (2014). An investigation of how the informal communication of firm preferences influences managerial honesty. A ccounting, Organizations and Society, 39(3), 195-207.

Salterio, S. E., \& Webb, A. (2010). Honesty in Accounting and Control: A Discussion of "The Effect of Information Systems on Honesty in Managerial Reporting: A Behavioral Perspective". Contemporary Accounting Research, 23(4), 919-932.

Schreck, P. (2015). Honesty in managerial reporting: How competition affects the benefits and costs of lying. Critical Perspectives on Accounting, 27, 177-188.

Schwering, A. (2017). The influence of peer honesty and anonymity on managerial reporting. Journal of Business Economics, 87(9), 1151-1172.

Thorpe, R., Holt, R., Macpherson, A., \& Pittaway, L. (2005). Using knowledge within small and medium-sized firms: a systematic review of the evidence. International Journal of Management Reviews, 7(4), 257-281. 